\title{
SOIL AND HUMAN HEALTH
}

\section{O. Bezuglova}

\author{
Southern federal university. Rostov-on-Don, Russian Federation \\ lola314@mail.ru
}

The environment in which a man and animals live, greatly affects their health. A range of serious diseases of unclear etiology are obliged to the soil composition on which the food eaten by animals and humans is grown. It was determined by the works of A.P. Vinogradov and V.V. Kowalski. Excess or lack of chemical elements, and even more a violation of their ratio, become the causes of thyroid diseases, the enamel tooth damage, the bone system diseases, etc. Such diseases of A.P. Vinogradov called endemic, and the territories with an anomalous content of chemical elements - biogeochemical or endemic provinces.

It is conditioned by the fact that many microelements participate in vitally important processes, occurring in the organism - hematosis, digestion, in the work of nervous and hormone systems. Microelements play the role of biological catalysts, being a part of enzymes, hormones and some vitamins, thereby influencing the growth, development, reproductive function. Not only by failures in the supply of microelements to the organism play the important role in the development of some or other diseases, but also by a violation of the balance between individual chemical elements, including macroelements. Thus, scientists associate an increased risk of stomach cancer with insufficient magnesium in food and water (but the primary reason is in soils), as well as with the violation of the ratio distortion in soil solution between the ions $\mathrm{Ca}, \mathrm{Mg}$ and $\mathrm{Mn}$. Magnesium promotes the correct absorption and use of calcium, as well as other important nutrients. If a lot of calcium comes with food, without enough magnesium, excessive calcium can practically become toxical, inducing diseased states in the organism. Even earlier, Rostov scientists V.V. Akimtsev, Z.M. Mitlin, I.I. Smolyaninov, who wrote the book "Soils and human health" in 1966, came to the conclusion about the extreme importance of the chemical elements correlation in soils, the effect of soil composition on the quality of products obtained on them, and the connection with the spread of cancer diseases. They were among the first in the scientific world to see and convincingly showed the relationship between the chemical composition of soils and the cancer spread. In particular, they found that the frequency of the gastric cancer occurrence dramatically increases in those areas of the Rostov region, Krasnodar Territory, North Ossetia, Dagestan, where the content of water-soluble magnesium in soils falls below the threshold $-0.002 \%$. quency

Key words: soils, biogeochemical provinces, endemic diseases, iodine deficit, stomach cancer fre-

\section{[Безуглова О.С. Почва и здоровье человека]}

Среда, в которой живет человек и животные организмы, в значительной степени влияет на их здоровье. Ряд тяжелых заболеваний неясной этиологии своим происхождением обязаны составу почвы, на которой выращиваются продукты питания, употребляемые в пищу животными и человеком. Установлено это было трудами А.П. Виноградова и В.В. Ковальского. Избыток или недостаток химических элементов, и в еще большей степени нарушение их соотношения, становятся причинами заболеваний щитовидной железы, повреждения зубной эмали, болезней костной системы и т.д. Такие заболевания А.П. Виноградов назвал эндемическими, а территории с аномальным содержанием химических элементов - эндемическими провинциями. Обусловлено это тем, что многие микроэлементы участвуют в жизненно важных процессах, происходящих в организме - кроветворении, пищеварении, работе нервной и гормональной систем. Входя в состав ферментов, гормонов и некоторых витаминов, микроэлементы играют роль биологических катализаторов, тем самым влияя на рост, развитие, репродуктивную функцию. Важную роль в развитии тех или иных заболеваний играет не только сбои в снабжении организма микроэлементами, но и нарушение соотношения между отдельными химическими элементами, в том числе и макроэлементами. Повышенный риск заболевания раком желудка ученые связывают с недостаточным содержанием магния в пище и воде (но первопричина - в почвах), а также с нарушением соотношения в почвенном растворе между ионами $\mathrm{Ca}, \mathrm{Mg}$ и $\mathrm{Mn}$. Магний способствует правильному усвоению и использованию кальция, а также других важных питательных веществ. Если в пищу поступает много кальция, без достаточного количества магния, избыточный кальций может фрактически стать токсичным, вызывая болезненные состояния в организме. Еще раньше к выводу о чрезвычайной важности соотношения химических элементов в почвах, влиянии состава почв 
на качество продуктов, получаемых на них, и связи с распространением раковых заболеваний пришли ростовские ученые В.В.Акимцев, З.М. Митлин, И.И. Смольянинов, написавшие в 1966 году книгу «Почвы и здоровье». Они одними из первых в научном мире увидели и убедительно показали связь между химическим составом почв и распространением рака. В частности, ими было установлено, что частота встречаемости рака желудка резко увеличивается в тех районах Ростовской области, Краснодарского края, Северной Осетии, Дагестана, где в почвах содержание водорастворимого магния снижается ниже порога - 0,002\%.

Ключевые слова: почвы, биогеохимические провинции, эндемические заболевания, йододефицит, встречаемость рака желудка.

Olga S. Bezuglova - Ph.D. of Biology, professor. Academy of Biology and Biotechnology of D.I. Ivanovsky. Southern federal university. Rostov-on-Don, Russian Federation

Безуглова Ольга Степановна - доктор биологических наук, профрессор. Академия биологии и биотехнологии им. Д.И. Ивановского. Южный федеральный университет. г. Ростов-на-Дону, Россия.

The environment in which a man and animals live, greatly affects their health. As it turned out, a number of serious diseases of unclear etiology are obliged to the soil composition on which the food eaten by animals and humans is grown. It was determined by the works of A.P. Vinogradov [2, 4], V.V. Kowalski [7]. Excess or lack of chemical elements, and even more a violation of their ratio, become the causes of thyroid diseases, the enamel tooth damage, the bone system diseases, etc. Such diseases of A.P. Vinogradov called endemic, and the territories with an anomalous content of chemical elements - biogeochemical or endemic provinces [2, 4] (1938, 1949). A.P. Vinogradov first showed that the development of goiter disease is directly related to the lack of iodine in soils [3]. Regional studies have confirmed this dependence. For instance, in the work of N.E. Pinchuk [9] it is shown that inhomogenuity of physiographic and Krasnodar region soil conditions determines the existence of territories with various content of gross iodine in the soil. The number of persons with abnormalities in the functional status of the thyroid gland depends on the iodine content in the environment, in particular, in the soil. This dependence appears to be the opposite: the higher the gross iodine content in the soil of the district, the less probability of iodine deficiency diseases occurrence of this region inhabitant. The relative number of people suffering from abnormalities in thyroid functional activity is higher in areas with low soil availability of total iodine (less $4 \mathrm{mg} / \mathrm{kg}$ ) (table 1). Immediate causes of iodine insufficiency in the organism are: iodine underconsumption and insufficient digestion of iodine by the organism, besides the last one is more often conditioned by the lack or abundance of microelements, influencing the iodine metabolism in the organism. Thus, the predominance of copper and cobalt over iodine in the soil increases sickness rate of hypothyrosis in the region [10].

Correlation of the gross iodine content in the soils of the Krasnodar Territory with thyroid gland dysfunction (according to: [6])

\begin{tabular}{|l|c|c|}
\hline \multicolumn{1}{|c|}{ Districts } & $\begin{array}{l}\text { lodine gross content, } \\
\mathrm{mg} / \mathrm{kg}\end{array}$ & $\begin{array}{l}\text { Number of inhabitants with thyroid } \\
\text { gland dysfunction, \% }\end{array}$ \\
\hline Absheronsky & $1-4$ & 46,61 \\
\hline Krasnoarmesky & $1-4$ & 40,13 \\
\hline Goryacheklyuchevskoy & $1-4$ & 41,52 \\
\hline Caucasian & $4-5$ & 31,95 \\
\hline Kanevskoy & $4-5$ & 30,67 \\
\hline Kuschevsky & $4-5$ & 32,26 \\
\hline
\end{tabular}


Environment contamination considers to be the other reason, influencing the iodine digestion by the organism. So called relative iodine insufficiency appears in this case: contaminants, primarily, induce insufficient iodine admission to the thyroid gland, but not generally to the organism. Particularly, iodine accumulative function of the thyroid gland is suppressed by the nitrates, salts of some heavy metals, bromidums. A row of chemical elements, contaminating natural water and food, restrains the tiroliberin production in the hypothalamus (carbon disulfide) or thyrotrophin in hypothalamus (lead), or violates the reaction of hypophysis to tiroliberin (fluoride), contributing the development of tertiary and secondary hypothyroidism. Phosphorus, nitrates, fluoro, iodides, carbonic oxide, sulphourea, cyanides, appearing to be the fermentative poisons, suppress or block iodine peroxidase or deiodase in the thyroid gland or monodeiodinase at the periphery (pesticides). Environmental pollution often damages the membranes of thyroid cells, destroying them, triggering the release of thyroglobulin into the blood, and contributing to autosensitization. In this respect, the synthetical detergents and urea are especially aggressive. Nitrates and uranium block the release of ready-made thyroid hormones into the bloodstream [10].

There is also evidence that the more severe the incidence of hypothyrosis, the higher the content of manganese in foods and the lower the content of molybdenum. On the other hand, it was found that bone disease develops with a lack of manganese in the soil in animals and humans, and as the iodine digestibility decreases, the development of goiter disease is also possible [5]. It is conditioned by the fact that many microelements participate in vitally important processes, taking place in the organism - hematosis, digestion, work of nervous and hormone system. Being a part of enzymes, hormones and some vitamins, microelements play the role of biological catalysts, thereby influencing the growth, development, reproductive function.

Not only by failures in the supply of microelements to the organism play the important role in the development of some or other diseases, but also by a violation of the balance between individual chemical elements, including macroelements. Thus, scientists associate an increased risk of stomach cancer with insufficient magnesium in food and water (but the primary reason is in soils), as well as with the violation of the ratio distortion in soil solution between the ions $\mathrm{Ca}, \mathrm{Mg}$ and $\mathrm{Mn}$ [11]. Magnesium promotes the correct absorption and use of calcium, as well as other important nutrients. If a lot of calcium comes with food, without enough magnesium, the excessive calcium can practically become toxical, inducing diseased states in the organism.

Even earlier, Rostov scientists, who wrote the book "Soils and human health" in 1966, came to the conclusion about the extreme importance of the chemical elements correlation in soils, the effect of soil composition on the quality of products obtained on them, and the connection with the spread of cancer diseases [1]. The triumvirate of scientists - pedologist, the head of the soil science department of Rostov state university, professor V.V. Akimtsev, doctors - the head of the surgical department of the Rostov cancer institute Z.M. Mitlin, and Ph.D of medical sciences, professor II. Smolyaninov, proved to be very fruitful: they were among the first in the scientific world to see and convincingly demonstrated this relationship between the chemical composition of soils and the spread of cancer. In particular, they found that the frequency of gastric cancer occurrence dramatically increases in those areas of the Rostov region, Krasnodar Territory, North Ossetia, Dagestan, where the content of water-soluble magnesium in soils falls below the threshold $-0.002 \%$ (Pic. 1 ). 


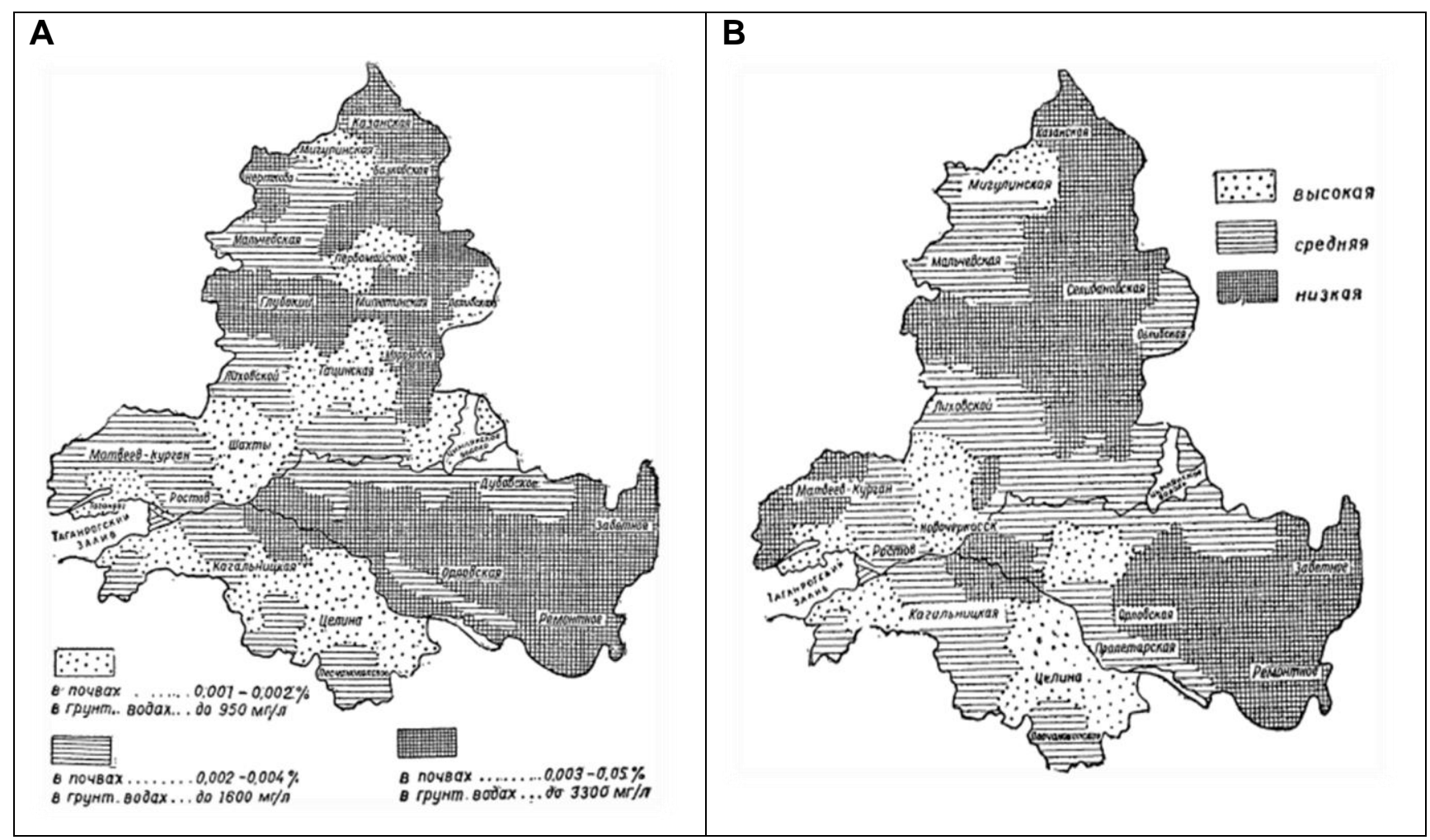

The content of water-soluble magnesium in the soils and groundwater of the Rostov Region (the cartogram was made by V.V. Akimtsev, P.A. Sadimenko) - A; The sickness rate of stomach cancer (cartogram was made by Z. M. Mitlin) - B.

Further, more in-depth study of Rostov region soils showed that regions marked by Z.M. Mitlin also differ in content of other elements. The soils of the first region contain a small amount of chloride salts and sulfates. They are also least provided with manganese, boron and cobalt and contain an average amount of copper, zinc and iodine. The amount of chlorides and sulphates increases by 3-4 times in soils in the second region, there are relatively many manganese, copper and zinc, slightly less the amount of boron and cobalt, and especially iodine. In the third region, the soil solutions are the most mineralized. They have the increased content of chlorides and sulphates, the amount of gross manganese and its mobile forms is much higher, as well as boron, cobalt, nickel and iodine.

The pattern established in the Rostov region was confirmed in the Krasnodar Territory. Here, the greatest number of stomach cancers was found mainly in the areas of forest podzolized soils on the Black Sea coast, strongly leached chernozems and meadow boggy soils in the basin of the middle and lower streams of the Kuban, the least provided with magnesium salts and trace elements. The smallest number of diseases is registered in some western, central and northeastern regions of the region, covered mainly by carbonate and chestnut chernozems, characterized by a high content of carbonates, reducing the mobility of many microelements.

It would seem that long-established facts should actively attract the attention of practitioners, and even more scientists. However, it is not like this. For instance, in a number of works, devoted to such a dangerous disease as mastopathy, there are indications of a higher occurrence of it in some regions of the Russian Federation. A simple comparison of these data with a map of biogeochemical zones and provinces indicates the areas that are not adequately provided with iodine. But it was not possible to meet the relevant conclusions or even the assumptions on this problem in scientific articles. But the correlation of 
mastopathy with thyroid disorders has long been known: $64 \%$ of patients with various forms of mastopathy have thyroid pathology. Hypofunction of the thyroid gland increases the risk of mastopathy in 3.8 times [8].

Hence the importance of soil joint studies of scientists and physicians, aimed at identifying cause and effect relationships in the occurrence and spread of certain diseases with the properties of the soil cover. That is why in 1986 the working group "Soils and Geomedicine" was organized within the framework of the international soil science society, but the activity of its work leaves much to be desired.

\section{Лumepamypa}

1. Акимцев В.В., Митлин З.М., Смольянинов И.И. Почвы и здоровье человека. M., 1966.

2. Виноградов А.П. Биогеохимические провинции и эндемии // Доклады АН CCCP. 1938. T.XVIII. № 4/5.

3. Виноградов А.П. Геохимия йода (геохимическая обстановка в областях с эндемическим зобом) // Известия АН СССР, серия географическая и геофизическая, 1946. Т.10. №4.

4. Виноградов А.П. Биогеохимические провинции // Труды Юбилейной сессии, посвященной 100-летию со дня рождения В.В.Докучаева, М.-Л., 1949.

5. Демко Е.Б. Влияние нарушения соотношения некоторых микроэлементов (йод, медь, кобальт и марганца) на щитовидную железу на фоне оптимального и несбалансированного питания. Автореф. дис. д-ра мед. наук. Смоленск, 1972.

6. Елисеева Н. В., Пинчук Н. Е. Нарушения тиреоидного статуса у пациентов Краснодарского края с различной обеспеченностью почв валовым йодом // Проблемы региональной экологии, 2006. №1.

7. Ковальский В. В. Геохимическая экология: очерки. М., 1974.

8. Мастопатия. Новые аспекты в лечении. Новосибирск, 2011.

9. Пинчук Н. Е. Особенности изменения фрунции щитовидной железы человека в зависимости от содержания йода в почвах Краснодарского края. Дис. к.б.н. Краснодар, 2005.

10.Цикуниб А.Д. Биохимия щитовидной железы. Методические указания. Майкоп, 2012.

11. Rude R.K., Shils M.E. Magnesium // Modern Nutrition in Health and Disease. 10th ed. Baltimore, 2006.

\section{References}

1. Akimtsev V.V., Mitlin Z.M., Smolyaninov I.I. Soil and human health. M., 1966.

2. Vinogradov A.P. Biogeochemical provinces and endemics // Reports of Academy of Sciences of the USSR. 1938. V.XVIII. No 4/5.

3. Vinogradov A.P. lodine geochemistry (geochemical situation in the spheres with hypothyrosis) // Izvestiya of Academy of Sciences of the USSR, geographical and geophysical series, 1946. V.10. No4.

4. Vinogradov A.P. Biogeochemical provinces // Writings of jubilee session, dedicated to 100-years from the date of birth of V.V. Dokuchaev, M.-L., 1949.

5. Demko E.B. Impact of the ratio violation of certain trace elements (iodine, cuprum, cobalt and manganese) on the thyroid gland on the back of optimal and unbalanced nutrition: abstract of a thesis of Ph.D. of medical studies. Smolensk, 1972. 
6. Eliseeva N.V., Pinchuk N. E. Defections of thyroid status of Krasnodar Territory patients with various gross iodine soil conditions // The problems of regional ecology, 2006. No1.

7. Kovalsky V. V. Geochemical ecology: essays. M., 1974.

8. Mastopathy. New aspects in treatment. Novosibirsk, 2011.

9. Pinchuk N. E. Alteration peculiarities of the human thyroid gland, depending the iodine content in the soils of Krasnodar Territory. Thesis of the candidate of biological studies. Krasnodar, 2005.

10. Tsikunib A.D. Thyroid gland biochemistry. Methodological instructive regulations. Maikop, 2012.

11. Rude R.K., Shils M.E. Magnesium // Modern Nutrition in Health and Disease. 10th ed. Baltimore, 2006. 